\title{
BCCIP Gene
}

National Cancer Institute

\section{Source}

National Cancer Institute. BCCIP Gene. NCI Thesaurus. Code C103955.

This gene may be involved in both cell cycle progression and DNA damage repair. 